TITOV SERGEY, Postgraduate Student, Religious Studies Department, Taras Shevchenko National University of Kyiv

\title{
ANALYSIS OF TABOOS AS A BASIC PRINCIPLE OF RELIGIOUS BELIEFS IN THE CONTEXT OF MODERN RELIGIOUS STUDIES
}

The article analyzes some definitions of a taboo, which are well-known in modern religious studies, and looks into a taboo generation mechanism (by the example of G. R. Stephenson's experiment with rhesus monkeys). The author considers that originally a taboo is a religious phenomenon and, proceeding from the above, systematizes the areas falling under its influence. Special attention is given to a number of prohibitions related to the sacred area. It is indicated that all the spheres of life in primitive societies are regulated by sacred taboos which replace law, ethics and religion. In civilized societies taboos are represented by verbalized forms of the sacred. The author asserts that any kind of a prohibition is of absolutely religious nature by its origin and draws a conclusion that the phenomenon of taboo is a particular case of a religious prohibition both in primitive societies and modern religious traditions. The novelty of the given research is an attempt to look for ontological grounds for taboo generation in terms of religious studies.

Key words: taboo; religious beliefs; archaic and modern cultures; taboo classification.

Definition of problem and level of its research. Numerous sociologic, philosophic, psychoanalytic and religious history studies examine the phenomenon of taboo. Most modern studies addressing the latter relate to social sciences. The reason is that it is in the sphere of social life where we still observe the operation of implicit laws and prohibitions. The latter are manifested as some lexical norms and taboo words, sexual prohibitions in the form of the age of consent and amendments to a respective law in case of a small age difference of partners breaching the age limit as well as the still existing incest taboo. Initially, however, when the term taboo was integrated in the European lexical field, the correlation of the taboo principle with religion was obvious. Following E. Durkheim's works and French social-anthropological school studies dedicated to the above phenomenon as well as respective psychoanalytical research, the interest to religious roots of taboos gradually came to naught. The author deals with a religious aspect of a taboo, making use of recent findings and sources.

The phenomenon of taboo was addressed by M. Douglas, E. Durkheim, S. Reinach, A. Radcliffe-Brown, M. Fortes, A. Taylor and H. Webster [1942]. Among contemporary works, of special interest are publications by Y. Borodai [1996], M. Makovsky [2012], E.Beliayeva, Anise K. Strong [2005] et al.

The object of the research is the taboo principle, its application in archaic and modern cultures as well as the notion taboo, its etymology and pattern of changes, depending on the historical context and religious aspect of culture.

The subject of the research is religious interpretation of taboos.

The aim of the research is a review of the existing religious interpretations of a taboo as well as an analysis of the genesis of prohibition systems by the example of archaic communities and on the basis of behavioral patterns of apes.

The research method is based on an analysis of the taboo evolution and study of the nature of its action in religion, ethics and social life as well as the evolution of the notion etymology from archaic cultures to modern manifestations. The genesis of the taboo principle itself in society, its roots and origination are traced back. The article also covers the incidence of the phenomenon in question.

Results. According to Academician A.A. Guseinov, the entire theory of morals comes to a principle of prohibitions. Intrinsically, a ban exists in the form of an undiscussable rule since its roots go deeply back to the historical and religious tradition which is protected against any attempt of interpretation [Guseinov. 2007]. A taboo is a kind of such prohibition and researchers in the field found different sources of its origin: religious, social, cultural and psychological.

The prohibition genesis is based on an attempt of man to explain some consequences which originate from the transcendental sphere. Any ban, any taboo may be therefore considered as an initially religious form which later transformed into a social rule or tradition.

The function of biblical prohibitions and prescriptions contained in the Book of Leviticus is to protect the established life forms from any infringements or interpretations and to retain the connection of the Judaic people with God. It is the definition of this connection, which gave rise to the term religion from the Latin word religare.

A well-known story about an experiment with rhesus monkeys, suspended bananas and cold water may be illustrative for understanding the taboo generation and action mechanism. The experiment aimed to artificially develop a taboo mechanism within a community. Specifically, a group of five monkeys were poured over with iced water the moment one of them tried to get bananas by using a ladder, available in the cage. All attempts of individual members of the group to reach a hand of bananas eventually ended up with collective punishment with cold water until they refused their vain attempts. The group was then gradually supplemented with new members, the old members removed from the cage to maintain the number of monkeys unchanged, five in our case. At that stage of the experiment iced water as an obstacle was not used any more but the old members severely suppressed any attempts of new arrivals to treat themselves with a hand of bananas below the ceiling. Later on, the group 
comprising only the monkeys who never knew the iced water punishment for getting bananas still beat an active new arrival aiming at the forbidden. And although the above story known from some sources dating back to the 1970 s is a fake and is based on similar experiments of the primatologist G.R. Stephenson whose arguments gave rise to the development of a similar model as a hypothesis, such behavioral pattern is absolutely probable [Stephenson, 1967: 279-288]. And the mechanism of the above behavior, evoking a smile, raises no much doubt. Some primatologists, commenting on the story in question, say that such experiment would have been rather costly in the late 1960s but if it were made today, there would be few to doubt that the result would be exactly the same [Maestripieri, 2012].

When analyzing such behavioral pattern of species under observation, monkeys rather than humans in this case, we can distinguish the following elements of the event:

1. Desire to satisfy one's need or get something (bananas in our case).

2. Punishment for the wrong-doing, which followed from an unknown source (from the transcendental sphere).

3. Casual interpretation of new experience, finding out the cause-and-effect relations between these two events, followed by punishment, or warning of the offender against some potentially more serious trouble.

4. Generation of a prohibition, based on observation.

5. Absence of an explanation of the prohibition and generation of a taboo with neither interpretation nor explanations, which subsequently turns into a tradition.

By analyzing and systematizing the areas impacted by a taboo, based on anthropological and religious studies conducted as well as works by J. Frazer [2014], L.Y. Shternberg [2012], S.A.Tokarev, A.F.Anisimov [1966] and $\mathrm{H}$. Webster [1942], we can single out the following groups of taboos: 1. Priesthood as a special social class, authorities (tribal chiefs and kings), as delegated by the sacred to govern, as well as rules and guidelines for contacting the sacred sphere. 2. Death and everything related to it, including burial and cleansing rituals and everyday life elements. 3. Sex and marriage rules as well as incest. 4. Standards defining the filth and the evil.

The Encyclopedia Britannica frugally defines a taboo as something sacred and consecrated or too dangerous. According to the author, this definition is succinct indeed and allows to regroup and understand many kinds of a taboo. Thus, for example, a subgroup of food taboos may be considered as a prohibition on eating the food offered in sacrifice or as a ban on consumption of totem animals, which is also related to religion or is dangerous to man.

As per the given classification of taboos, we have two groups: 1 . The sacred and 2 . The dangerous.

The first group includes:

1.1 sacred personalia and their physical and verbal personification (god's name, idols),

1.2 those servants who are the closest to the sacred than the others (priesthood, leaders and their families),

1.3 sacred territories (theophany and revelation places, places of power etc.),

1.4 sacred representatives and intermediaries of flora and fauna (totems).

The second group is related to perceptions and practices (specifically those protecting), incidental to death and filth, and comprises:

2.1 funeral ceremonies and practices of contacting the dead,

2.2 taboo related to women's monthlies and childbearing.

Any food taboos are one way or another connected with the first or second groups.
As an example, sacred sacrificial or totem food pertains to the first group and a prohibition on touching food after a burial and ablution of a dead body falls into the second group. The latter case was described by J. Cook during his fist sailing as an illustrative example of taboos. Special food rules for parturient and menstruating women may be also referred to this group.

There are also other forms of taboos, specifically the known incest one. But its interpretation and generation mechanism, well covered in works by R. Caillois and R. Girard [2010], are rather of anthropological and sociological interest.

To learn the religious nature of taboos, it is important to address the first group bans, namely those related to the sacred area.

Pointing out the borrowing of the term from ritualism of archaic peoples of Polynesia, the Russian anthropologist L.Y. Shternberg wrote that outlined manifestations of religious bans under different names had been typical for all the existing peoples despite their different development stages. Most bans and respective rites are unexplainable even from the viewpoint of followers of those standards and may be accounted for by ancient traditions and historical justification of the time-tested religious demand [Shternberg, 2012: 186]. According to L.Y. Schternberg, at the bottom of all those prohibitions is a desire to protect and retain a reasonable religious rule by way of restrictions and regulations of actions associated with one or another phenomenon, often the sacred one [Shternberg, 2012: 186-190]. The Jewish Talmud names such prohibitions the fences of law. An example of such strict regulation is standards of conduct on Saturdays. A Jew is not then allowed to light a match or even press a button of an elevator. Another example is separation of meat and dairy cuisines in order to avoid breaking the Torah commandment: "The first of the first-fruits of thy land thou shalt bring into the house of the LORD thy God. Thou shalt not seethe a kid in his mother's milk" [Exodus. 23:19]. It can be pointed out in this respect that in the modern Israeli army there are two separate premises for doing the dairy and meat dishes.

When the hieratic priesthood appeared, the systems of bans were transformed into whole institutes, extending to standards of behavior and some social systems. The process manifested itself by numerous regulations in social life, law and ethics.

In modern archaic societies where taboo systems are well manifested and not hidden behind complex cultural, religious and traditional layers like taboos in Europe, said systems regulate all forms of life, replacing sophisticated rules of legal right, civil law, ethics and religion.

Adherence to tight standards of behavior by the Jews indicates their treatment of law and restrictive rules as an ontological, basic and affirmative life principle expressed in the maximal obedience to God. In this context Christianity demonstrates an explicit retreat from stringent regulations by ontologically bringing forward the principle of love of God and love for neighbors. Torah, the Book of Leviticus, features strict descriptivity of the products to be eaten and prohibited to be eaten. Direct prescriptions as imperative statements read as follows: "Of their flesh shall ye not eat, and their carcass shall ye not touch; they are unclean to you" [Leviticus, 11:8] or "And all that have not fins nor scales in the seas, and in the rivers, of all that move in the waters, and of any living animal which is in the waters, they shall be an abomination to you" [Leviticus, 11:10-11].

The sacred sphere and everything it was represented by on earth, namely temples, holy sites, priests and their property, fell within the protective scope of taboos. Moreover, authorities who allegedly originated from gods were also 
taboos. Anything touched by a king or a chief, a path he used to walk along, a house he came in, became a taboo for the others.

In his work "Spiritual Life of Primitive Society" the anthropologist F.A. Anisimov gives the following example. The Chiefs of some tribes never blew the fire because the latter, having become sacred, would make the food and the pottery for its cooking sacred too. Ordinary people would not be able to eat such food otherwise they would be punished by the penalty of death [Anisimov, 1966: 150]. Taboos also extend to certain sacred periods related to specific celebrations or preparations, for example preparation for war. Certain periods dictated well-defined canons of behavior, associated with attendance of divine services, rules of eating and conduct, bans on boating and swimming or simply keeping complete silence. L.Y. Shternberg writes about behavioral standards of a Hawaiian tribe in his work "Primitive Religion in the Light of Ethnography": "Bans extended even to animals: dogs were prohibited to bark, roosters to crow and pigs to grunt. To hinder that, the Hawaiians used to bind dogs' muzzles and pigs' snouts whereas birds were placed under pumpkins or blindfolded with a square of some cloth" [Shternberg, 2012: 186-190].

The fear of inexplicable natural forces builds such human behavioral patterns which enable man to adapt and survive. It is difficult living conditions and a contact with incomprehensible and unexplainable (sacred or transcendental) forces, which give rise to some systems of rules of conduct in communities of primates in the first pace and in communities of the first homines afterwards. And any codes of behavior are primarily a system of restrictions. Among the first rules of the kind was cautious handling of Lower Paleolithic predators such as lions, homotherini, hyenas and bears when trying to get remnants of their food. The nature of food of the first homines enabled them to reach carcasses left by lions and homotherini faster than hyenas. That nutritive process of man the scavenger was detailed in works by B.F. Porshnev [2006], S. Drobyshevsky [2017] and A. Markov [2014]. The key category which generated systems of subsequent prohibitions was fear. It should be noted that today man pays particular attention to negative information in media and other sources. It would be therefore correct to explain the phenomenon in terms of pragmatic utility. Negative information is more valuable for survival than positive or comforting. Permanent alertness and the ability to consider the first signs of an imminent threat are a guarantee of survival. Any prescriptions based on fear are therefore worthy of being followed and kept to from the viewpoint of both archaic and modern man. "The fear of the LORD is the beginning of knowledge [Proverbs; 1:7]. Any manifestations of inexplicable forces give rise to such interpretations in the mind of archaic man, which are associated with the transcendental and supernatural. The supernatural sphere is the divine one and communication with it needs clear regulation so as to avoid falling into disgrace. This is the reason why people who commune with it form a particular social class. They are delegated a solemn mission of contacting the sacred and they become bearers of taboos themselves.

According to L.Y.Schternberg, a taboo itself is irrational and unexplainable for its bearers but fear and caution make them adhere to the tradition. "Observance of taboos was secured by repressive measures (death penalty, deprivation of property, plunder of orchards, fines in favor of persons having introduced taboos etc.) and fear of divine retribution (allegedly, an evil spirit gets into the body and eats the offender's entrails). It happened that people who unfortunately had broken a taboo suddenly died in fear of the inevitable scourge of God" [Shternberg, 2012: 186-190]. L.Y.Shternberg continues: "However, with the arrival at the Hawaiian Islands in the 1920s of the first Europeans who got away with violating the most sacred taboos under the locals' very eyes, the people were much pleased to follow the lead of some royal family members and finally release themselves from a terrible yoke of the taboo system"' [Shternberg, 2012: 186-190].

Taboo forms of verbalization of the sacred are doubtlessly present in modern society and modern languages. It may be exemplified by a Jewish ban on pronouncing the name of God and a Christian prohibition on naming any personalia of dark forces of evil. Another example is the loss of the original name of a bear in the Slavic (Russian, Ukrainian) languages, which has survived only in the form of a descriptive characteristic that subsequently acquired a complete etymological load. The traces of a previous name, consonant with other European languages, have survived in the description of this animal's dwelling, namely "ber-loga". A bear is considered a sacred animal in numerous traditions of the north, specifically in shamanistic cults. For example, the Nivkhs call a bear a "master's dog". Cultures of the Paleolithic age, ranging from Mousterian to Gravettian and Magdalenian, feature certain hunter cults associated with a bear.

\section{Conclusion}

According to the author, the phenomenon taboo is a particular case of a religious ban which exists both in primitive communities and modern religious traditions. Furthermore, taboos of primitive peoples are inexplicable and beyond interpretation because initially they have a sacred source of origin in the causality chain. The taboo principle has been illustrated by an enormous number of examples in anthropological literature. Due to the nature of interests of $20^{\text {th }}$ century scholars (S. Freud, E. Durkheim), those examples underlay important sociological and psychological theories rather than religious studies. However, basically, bans are rooted in the sacred and our idea of it. In other words, bans and taboos are of religious origin. Modern primatology and ethology also offer lots of interesting examples that illustrate a taboo as a phenomenon while enabling us to track its generation mechanism. They also prove to satisfaction that, on the one part, a taboo is an inexplicable prohibition beyond interpretation, which dictates strict behavior and, on the other part, a taboo has a transcendental source of origin as its ontological basis.

\section{REFERENCES}

1. Anisimov, A.F. 1966. Spiritual life of primitive society. Moscow - Leningrad, 243 p. (rus).

2. Boroday, Yu. M. 1996. Erotica - Death - Taboo: the tragedy of human consciousness. Gnosis, Russian Phenomenological Society, Moscow, 416 p. (rus).

3. Guseinov, A.A. 2007. Negative ethics. (Selected lectures of the University, issue 63) Publishing house SPbGUP, Available at: https://guseinov.ru/publ/Negat_eth.html (Accessed: 05.05.2018).

4. Drobyshevsky, S. 2017. Remaining link. Book one: People. AST- CORPUS, Moscow, 592 p. (rus).

5. Girard, Rene. 2010. Violence and the sacred [Translat.] New literary review, Moscow, $448 \mathrm{p}$.

6. Makovsky, M.M. 2012. The phenomenon of the TABU in the traditions and in the language of the Indo-Europeans: The essence of form, development. Moscow, 280 p. (rus).

7. Markov, A. 2014. The evolution of man. Vol. 2. Monkeys, neurons and soul. AST Publishing, Moscow, 512 p. (rus).

8. Porshnev, B.F. 2006. On the beginning of human history (Problems of Paleopsychology). Fairy-V Publishing, Moscow, 640 p. (rus). 
9. Fraser, J. 2014. Gold branch. New translations (study of magic and religion) [translat.] Academic Project, Moscow, 407 p. (rus).

10. Freud, S. 2008. Totem and the Taboo. Psychology of primitive culture and religion. Questions of society and the origin of religion. Firma STD Ltd, Moscow, 285-444 (rus).

11. Shternberg, L. 2012. Primitive religion in the light of ethnography: Studies, articles, lectures. The book house "Librocom", Moscow, 92 p. (rus).

12. Strong, Anise K. 2005. Incest Laws and Absent Taboos in Roman Egypt. Available at: https: //www.academia.edu/205164/ Incest_Laws_and_Absent_Taboos_in_Roman_Egypt (Accessed: 30.04.2018)

13. Maestripieri, Dario, 2012. What Monkeys Can Teach Us

Титов Сергій,

аспірант кафедри релігієзнавства, Київский національний університет ім. Т. Шевченка
About Human Behavior: From Facts to Fiction. Available at: https:/ /www.psychologytoday.com/intl/blog/games-primates-play/ 201203/what-monkeys-can-teach-us-about-human-behaviorfacts-fiction (Accessed: 05.04.2018).

14. Encyclopaedia Britannica. Taboo Available at: https:// www.britannica.com/topic/taboo-sociology (Accessed: 25.04.2018).

15. Stephenson, G. R. 1967. Cultural acquisition of a specific learned response among rhesus monkeys. In: Starek, D., Schneider, R., and Kuhn, H. J. (eds.), Progress in Primatology, Stuttgart: Fischer, pp. 279-288.

16. Wagner, Roy. 2005. Taboo. In: Jones Lindsay [editor in chief]. Encyclopedia of religion (2nd ed.). Macmillan Reference USA. Thomson Gale: 8947-8949.

17. Webster, Hutton. 1942. Taboo: A Sociological Study. Stanford, Calif., 393 p.

\section{АНАЛІЗ ТАБУ ЯК БАЗОВОГО ПРИНЦИПУ РЕЛІГІЙНИХ ВІРУВАНЬ У КОНТЕКСТІ СУЧАСНОГО РЕЛІГІЕЗНАВСТВА}

У статті розглянуто механізм виникнення табу (на прикладі експерименту Дж. Р. Стівенсона 3 макакамирезусами), проаналізовані деякі відомі в сучасному релігієзнавстві визначення феномена, зокрема, $X$.Вебстера (1942), С.А.Токарева і А.Ф. Анісімова (1966), А Гусейнова (2007), Л.Я. Штернберга (2012) і виділені дві групи табу, пов'язані зі сферою його дії - сакральні та небезпечні. Досліджуючи релігійний характер табу, особливу увагу автор приділяє групі заборон, пов'язаних зі сферою сакрального. Показано, що в примітивних суспільствах сакральні табу регламентують усі сфери житт, замінюючи право, мораль і релігію. У цивілізованих суспільствах табу представлені вербалізованими формами сакрального. У зв'язку з цим він відзначає прагматичну корисність негативної інформації в медіа або інших джерелах масової інформації - негатив стимулює людську здатність вслухатися в перші ознаки загрози, що насувається, а отже попереджати подібні випадки в майбутньому, будь-які приписи, засновані на страху, заслуговують 3 точки зору і давньої, і сучасної людини, право на те, що б їм наслідувати іїх дотримуватися. Автор стверджує тотально релігійний характер походження будь-яких видів заборон і робить висновок, що феномен табу є окремим випадком релігійної заборони, як у примітивних суспільствах, так і в сучасних релігійних традиціях. При цьому табу примітивних народів є незрозумілими і не підлягають інтерпретації саме в силу того, що від початку в казуальному ланцюжку мають сакральне джерело походження. Новизною даного дослідження $є$ спроба пошуку онтологічних підстав походження табу в релігієзнавчому аспекті.

Ключові слова: табу; релігійні вірування; архаїчні і сучасні культури; класифрікація табу.

\section{ЛITEРАТУРА}

1. Анисимов А.Ф. Духовная жизнь первобытного общества. М.-Л., 1966. 243 с.

2. Бородай Ю. М. Эротика - смерть - табу: трагедия человеческого сознания. М.: Гнозис, Русское феноменологическое общество, 1996. 416 с

3. Гусейнов А. А. Негативная этика СПб.: Изд-во СПбГУП, 2007. (Избранные лекции Университета; вып. 63). URL: https:// guseinov.ru/publ/Negat_eth.html (дата обращения 05.05.2018).

4. Дробышевский С. Достающее звено. Книга первая: Люди. Москва: АСT:CORPUS, 2017. 592 с.

5. Жирар Рене. Насилие и священное / пер. с франц. Г.Дашевского. Москва: Новое литературное обозрение, 2010.448 с.

6. Маковский М.М. Феномен ТАБУ в традициях и в языке индоевропейцев: Сущность формы, развитие. Изд. 4-е. Москва: Книжный дом "Либриком", 2012. 280 с.

7. Марков А. Эволюция человека. В 2 кн. Кн. 2. Обезьяны, нейроны и душа. Москва: АСТ, 2014. 512 с.

8. Поршнев Б.Ф. О начале человеческой истории (Проблемы палеопсихологии). Москва: Фэри-В, 2006. 640 с.

9. Фрезер Дж. Золотая ветвь. Новые переводы (исследование магии и религии) / пер. с англ. - 2-е узд., ред. С.А. Токарева. Москва: Академический Проект, 2014. 407 с.

10. Фрейд 3. Тотем и табу. Психология первобытной культуры и религии. Зигмунд Фрейд. Вопросы общества и происхождения религии. Москва: ООО "Фирма СТД", 2008. С. 285-444.

11. Штернберг Л.Я. Первобытная религия в свете этнографии: Исследования, статьи, лекции / сост. С.А. Ратнер-Штернгерг; под ред. Я.П. Алькора. Изд. 2-е. М.: Книжный дом "Либроком", 2012. 592 с.

12. Anise K. Strong. Incest Laws and Absent Taboos in Roman Egypt. URL: https: //www.academia.edu/205164/ Incest Laws and Absent Taboos in Roman Egypt (дата обращения 30.04.2018)

13. Dario Maestripieri Ph.D. What Monkeys Can Teach Us About Human Behavior: From Facts to Fiction. URL: https:// www.psychologytoday.com/intl/blog/games-primates-play/201203/what-monkeys-can-teach-us-about-human-behavior-facts-fiction (дата обращения 05.04.2018).

14. Encyclopaedia Britannica. Taboo. URL: https://www.britannica.com/topic/taboo-sociology (дата обращения 25.06.2018).

15. Stephenson, G. R. Cultural acquisition of a specific learned response among rhesus monkeys. In: Starek, D., Schneider, R., and Kuhn, H. J. (eds.), Progress in Primatology, Stuttgart: Fischer, 1967, pp. 279-288.

16. Wagner Roy. Taboo / Encyclopedia of religion / Lindsay Jones, editor in chief. 2nd ed. Macmillan Reference USA. Thomson Gale: 2005. p. 8947-8949

17. Webster Hutton. Taboo: A Sociological Study. Stanford, Calif., 1942. 393 p.

(c) Titov Sergey

Надійшла до редакції 30.05.2018 